\title{
How heat stress (continuous or cyclical) interferes with nutrient digestibility, energy and nitrogen balances and performance in broilers
}

\author{
Lilian Francisco Arantes de Souza, Lívia Pegoraro Espinha, Eduardo Alves de Almeida, \\ Raquel Lunedo*, Renato Luís Furlan, Marcos Macari \\ Department of Animal Morphology and Physiology, College of Agriculture and Veterinary Sciences, São Paulo State University (UNESP), Via de Acesso Paulo \\ Donato Castellane s/n, CEP: 14884-900 Jaboticabal, São Paulo, Brazil
}

\section{A R T I C L E I N F O}

\section{Article history:}

Received 23 November 2015

Received in revised form

30 August 2016

Accepted 31 August 2016

\section{Keywords:}

Cyclical heat stress

Continuous heat stress

Nutrient digestibility

Heat production

Nitrogen efficiency

Pair-feeding

\begin{abstract}
A B S T R A C T
The effect of continuous and cyclical heat stress on broiler growth performance, nutrient digestibility, energy and nitrogen balances was investigated. Four hundred and fifty, 21-day-old, Cobb male broilers were raised in battery cages in five treatments: $22 \mathrm{C} / \mathrm{AL}$ (continuous $22^{\circ} \mathrm{C}$, ad libitum feed consumption); $32 \mathrm{C} / \mathrm{AL}$ (continuous $32{ }^{\circ} \mathrm{C}$, ad libitum feed consumption); $22 \mathrm{C} / \mathrm{PF} 32 \mathrm{C}$ (continuous $22^{\circ} \mathrm{C}$, pair-fed on the daily feed intake of $32 \mathrm{C} / \mathrm{AL}$ ); $\mathrm{CY} / \mathrm{AL}$ (cyclical $-32^{\circ} \mathrm{C}$ for $8 \mathrm{~h}$ and $25^{\circ} \mathrm{C}$ for $12 \mathrm{~h}$, ad libitum feed consumption); $22 \mathrm{C} / \mathrm{PFCY}$ (continuous $22^{\circ} \mathrm{C}$, pair-fed on the daily feed intake of $\mathrm{CY} / \mathrm{AL}$ ). Between 39 and 42 days of age, dry matter, crude protein, crude fat and $\mathrm{AME}_{\mathrm{n}}$ were analyzed in the diets and excreta to determine nutrient digestibility. Energy and nitrogen balances were evaluated through comparative slaughter ( 21 and 42 days of age). Growth performance was significantly lower in broilers exposed to either continuous or cyclical heat stress. However, the cyclical heat stress had a lower effect on feed intake and weight gain and no effect on the feed conversion rate. Nutrient digestibility was only influenced by continuous heat exposure, decreasing dry matter $(3.9 \%)$ and protein digestibility $(9.7 \%)$ in comparison to control birds. Broilers exposed to continuous heat stress increased metabolizable energy intake (20.3\%) and heat production (35.5\%), and decreased energy retention (20.9\%) and energy efficiency (32.4\%) in relation to control ones. Nitrogen intake and nitrogen retention were reduced by both forms of heat exposure, in comparison to control, but more strongly under continuous heat. Nitrogen retention was reduced by $50.4 \%$ and $20.4 \%$, for continuous or cyclical heat stress, respectively. Nitrogen efficiency was reduced only by the continuous heat exposure (33.1\%). These results revealed important differences between the effects of a continuous or a cyclical heat exposure in broiler chickens for digestibility, performance and energy and nitrogen balances.
\end{abstract}

(c) 2016 Elsevier B.V. All rights reserved.

\section{Introduction}

Heat stress causes great losses to the poultry industry, and especially, the broiler industry. In addition to the concerns regarding performance impairment, recently there has been increased research on the effects of heat stress due to the increased pressure of "global warming" (Gregory, 2010; Nardone et al., 2010).

Broilers under heat stress conditions show decreased feed intake. While this drop in feed consumption (Dale and Fuller, 1979; Abu-Dieyeh, 2006) affects weight gain and the feed conversion ratio, it does not fully explain the complete damage to growth performance. Hence, it is necessary to isolate the effects of high temperature per se from the effects of reduced feed intake in response to the heat stress.

\footnotetext{
* Corresponding author.

E-mail address: bln.raquel@yahoo.com.br (R. Lunedo).
}

Bonnet et al. (1997) concluded that some of the broiler performance loss caused by continuous heat exposure can be attributed to a decrease in nutrient digestibility. This effect could be due to peripheral vasodilation and reduced blood flow in the gut. However, the high temperature effect per se in metabolizable energy remains controversial, showing, depending upon the study, an increase (Keshavarz and Fuller, 1980), a decrease (Yamazaki and Zi-Yi, 1982) and no effect (Geraert et al., 1992; Faria Filho et al., 2007). Furthermore, continuous heat exposure directly affects carcass composition and energy metabolism, independently of feed consumption (Geraert et al., 1996). Protein metabolism is also affected through a decrease in nitrogen consumption and body retention (Temim et al., 1999). Finally, Temim et al. (2000) found decreases in muscle protein deposition in heat-stressed $\left(32^{\circ} \mathrm{C}\right)$ broiler chickens at 5-6 weeks of age, mainly by reducing protein synthesis, but also by an increase in proteolysis.

Gonzales-Esquerra and Leeson (2006) demonstrated the importance of distinguishing the type of heat exposure in broiler 
experiments. Continuous heat stress was most widely used in research that isolated the direct effect of heat from the feed intake reduction on the metabolism of birds (Geraert et al., 1996; AbuDieyeh, 2006). However, continuous heat stress does not normally occur in natural environments, and the effects described for continuous heat exposure cannot occur in cyclical heat conditions (Mashaly et al., 2004).

This study tested the hypothesis that growth performance, nutrient digestibility, and energy and nitrogen balances will respond differently in broiler chickens exposed to either a continuous or a cyclic heat stress between 21 and 42 days of age.

\section{Materials and methods}

\subsection{Birds and Management}

This study was conducted in accordance with the ethical principles for animal experimentation adopted by the Brazilian College of Experimentation (COBEA), and with approval of the local Committee for Ethical Animal Use (CEUA), Protocol 019508/ 09, São Paulo State University (UNESP), Jaboticabal, SP, Brazil.

The birds were raised in three climate-controlled chambers, measuring $6.0 \mathrm{~m} \times 8.0 \mathrm{~m}$, with concrete floors. The walls and ceilings consisted of insulating material with four exhaust fans. The chambers were equipped with cooling systems and infrared lamps, all thermostatically controlled. Ninety (90) battery cages $1 \mathrm{~m}$ wide, $0.60 \mathrm{~m}$ deep and $0.40 \mathrm{~m}$ high, with 5 birds/cage were used. The cages had wire flooring, trough feeders and cup waters.

Four hundred fifty (450), one-day-old male Cobb broiler chicks were first brooded in wood shaving bedding. All birds received the same diet (Table 1) until 21 days of age and were grown at the temperature recommended for Cobb $500^{\mathrm{TM}}$ broilers. At 21 days of age, the birds were weighed and experimental units were composed of chickens with the same average weight.

The birds were transferred to battery cages and distributed in a completely randomized design with five treatments: $22 \mathrm{C} / \mathrm{AL}$ (continuous $22{ }^{\circ} \mathrm{C}$, ad libitum feed consumption); 32C/AL (continuous $32{ }^{\circ} \mathrm{C}$, ad libitum feed consumption); 22C/PF32C (continuous $22^{\circ} \mathrm{C}$, pair-fed on the daily feed intake of $32 \mathrm{C} / \mathrm{AL}$ ); $\mathrm{CY} / \mathrm{AL}$ (cyclical $-32{ }^{\circ} \mathrm{C}$ for $8 \mathrm{~h}$ and $25^{\circ} \mathrm{C}$ for $12 \mathrm{~h}$, ad libitum feed consumption); $22 \mathrm{C} / \mathrm{PFCY}$ (continuous $22^{\circ} \mathrm{C}$, pair-fed on the daily feed intake of $\mathrm{CY} / \mathrm{AL}$ ) (Table 2). There were five treatments with six replicates of 15 birds each (three cages of 5 birds/cage), totaling 30 experimental units. The birds were subjected to the experimental treatments from 21 to 42 days of age.

For the continuous heat treatments (treatments with the prefix " $22 \mathrm{C}$ " and " $32 \mathrm{C}$ "), the birds were subjected to a constant temperature of 22 and $32{ }^{\circ} \mathrm{C}$, respectively. For the cyclical treatment (CY/AL), the birds were subjected to an oscillating temperature scheme of $8 \mathrm{~h}$ at $32{ }^{\circ} \mathrm{C}(9 \mathrm{~h} 00$ to $17 \mathrm{~h} 00)$ and $25^{\circ} \mathrm{C}$ for $12 \mathrm{~h}$ (19h00 to 7h00), with $2 \mathrm{~h}$ to elevate the temperature from $25^{\circ} \mathrm{C}$ to $32{ }^{\circ} \mathrm{C}$ and $2 \mathrm{~h}$ to reduce the temperature from $32{ }^{\circ} \mathrm{C}$ to $25^{\circ} \mathrm{C}$. The climatic chambers had no humidity control, and the average relative humidity throughout the experiment was $66 \%, 60 \%$, and $68 \%$ for the $22 \mathrm{C}, 32 \mathrm{C}$, and CY chambers, respectively.

All birds received the same diet, formulated according to Rostagno et al. (2005) (Table 1). Birds reared in 22C/AL, 32C/AL, and $\mathrm{CY} / \mathrm{AL}$ were fed ad libitum. For the 22C/PF32C and 22C/PFCY treatments, birds were allocated (in four portions) the same amount of feed consumed by the birds in the 32C/AL and CY/AL treatments on the previous day. The pair-feeding schedule was used to separate the effects of temperature from the effects of feed intake. The lighting regimen was 23:1 h light: dark. This program was used due to the melatonin effect of feed intake (Phetteplace and Nockels, 1985; Clark and Classen, 1995).
Table 1

Ingredient and nutrient composition of broiler diets.

\begin{tabular}{|c|c|c|}
\hline Ingredients (\%) & Starter (1-21 days) & Grower (22-42 days) \\
\hline Corn & 57.96 & 58.47 \\
\hline Soybean meal ${ }^{\mathrm{a}}$ & 35.62 & 32.42 \\
\hline Soybean oil & 2.57 & 5.47 \\
\hline Dicalcium phosphate $^{\mathrm{b}}$ & 1.82 & 1.68 \\
\hline Limestone & 0.99 & 0.95 \\
\hline Salt & 0.44 & 0.40 \\
\hline Choline chloride (60\%) & 0.10 & 0.10 \\
\hline DL-methionine (99\%) & 0.15 & 0.14 \\
\hline L-lysine $\mathrm{HCl}(78 \%)$ & 0.16 & 0.18 \\
\hline Vitamin-mineral premix ${ }^{\mathrm{c}}$ & 0.10 & 0.10 \\
\hline Antibiotic $^{\mathrm{d}}$ & 0.04 & 0.04 \\
\hline Coccidiostat $^{\mathrm{e}}$ & 0.05 & 0.05 \\
\hline \multicolumn{3}{|l|}{ Calculated analysis } \\
\hline Metabolizable energy (MJ/kg) & 12.55 & 13.39 \\
\hline Crude protein (\%) & 21.40 & 20.00 \\
\hline Calcium (\%) & 0.96 & 0.90 \\
\hline Available phosphorus (\%) & 0.45 & 0.42 \\
\hline Sodium (\%) & 0.22 & 0.20 \\
\hline Potassium (\%) & 0.83 & 0.77 \\
\hline Chlorine (\%) & 0.37 & 0.35 \\
\hline Choline (ppm) & 1950 & 1868 \\
\hline Digestible lysine (\%) & 1.14 & 1.08 \\
\hline Digestible Methionine (\%) & 0.45 & 0.42 \\
\hline
\end{tabular}

a Soybean meal contains $45 \%$ CP.

b Dicalcium phosphate contains $24.5 \%$ of calcium and $18.5 \%$ of available phosphorus.

${ }^{\mathrm{c}}$ Composition of vitamin-mineral premix per $\mathrm{kg}$ of product: vitamin $\mathrm{A}$ 7,000,000 UI; vitamin D3 3,000,000 UI; vitamin E 25,000 mg; vitamin $\mathrm{K} 980 \mathrm{mg}$; vitamin B1 $1780 \mathrm{mg}$; vitamin B2 $9600 \mathrm{mg}$; vitamin B6 $3465 \mathrm{mg}$; vitamin B12 $10,000 \mathrm{mcg}$; nicotinic acid $34,650 \mathrm{mg}$; calcium pantothenate $9500 \mathrm{mg}$; biotin $1600 \mathrm{mg}$; copper $10,000 \mathrm{mg}$; iodine $1300 \mathrm{mg}$; manganese $76,260 \mathrm{mg}$; selenium $273.6 \mathrm{mg}$; zinc 91,250 mg; antioxidant (Butylated hydroxytoluene) $100 \mathrm{mg}$.

d Zinc bacitracin $15 \%$

e Salinomycin sodium $12 \%{ }^{\mathrm{R}}$.

Table 2

Treatments according to temperature/feeding (21-42 days of age).

\begin{tabular}{lll}
\hline Treatment & Temperature $\left({ }^{\circ} \mathbf{C}\right)$ & Feeding \\
\hline $22 \mathrm{C} / \mathrm{AL}$ & 22 constant & Ad libitum \\
$32 \mathrm{C} / \mathrm{AL}$ & 32 constant & Ad libitum \\
$22 \mathrm{C} / \mathrm{PF} 32 \mathrm{C}$ & 22 constant & Pair-fed to $32 \mathrm{C} / \mathrm{AL}^{\mathrm{a}}$ \\
$\mathrm{CY} / \mathrm{AL}$ & 32 cyclic & Ad libitum \\
$22 \mathrm{C} / \mathrm{PFCY}$ & 22 constant & Pair-fed to $\mathrm{CY} / \mathrm{AL}^{\mathrm{a}}$ \\
\hline
\end{tabular}

a Continuous and cyclic heat exposed broilers' (32C/AL and CY/AL) feed intake was measured daily and allocated to $22 \mathrm{C} / \mathrm{PF} 32 \mathrm{C}$ and $22 \mathrm{C} / \mathrm{PFCY}$, respectively.

\subsection{Measurements}

Growth performance was evaluated from 21 to 42 days of age through feed intake (FI), body weight gain (BWG), feed conversion rate (FCR), and mortality (MORT). From 39 to 42 days of age, after an adaptation period of 3 days, total excreta was collected to measure the nutrient digestibility. Excreta was collected twice a day (7:00 a.m. - morning collection - and 6:00 p.m. - afternoon collection), pooled and frozen. Later, it was dried at $55^{\circ} \mathrm{C}$ for $72 \mathrm{~h}$ and ground. The 22C/PF32C and 22C/PFCY groups were fed 8 times a day during the digestibility assay. Diets and excreta were analyzed in triplicate to determinate dry matter, crude protein and crude fat according to AOAC (1984). The apparent metabolizable energy was adjusted for nitrogen balance $\left(\mathrm{AME}_{\mathrm{n}}\right)$ according to the methodology of Hill and Anderson (1958) using a PARR 1281 adiabatic calorimeter. Dry matter (DMD), crude protein (CPD), and crude fat (CFD) digestibility were calculated from the differences between nutrient excretion (excreta) and ingestion (diet). The digestibility values were calculated as a percentage. 
At 21 and 42 days, ten (control, before start the experimental period) and twelve birds (for each treatment at the end of experimental period), respectively, were desensitized by $\mathrm{CO}_{2}$ inspiration and sacrificed by cervical dislocation for energy and protein metabolism analyses using the comparative slaughter method (Blaxter, 1989). The birds were fasted for $12 \mathrm{~h}$, sacrificed, and the entire carcass (including viscera, blood, head, feet and feathers), frozen. After thawing, the entire carcasses were ground and dried at $55{ }^{\circ} \mathrm{C}$ for $72 \mathrm{~h}$ and the dry matter, crude protein and energy, as previously described in nutrient digestibility, were determined. Energy retention (ER) was calculated by the difference between the 42 and 21-day samples. Heat production (HP) was calculated by the metabolizable energy intake less retained energy, and expressed as $\mathrm{MJ} / \mathrm{kg}^{0.75} /$ day. Energy efficiency (EE) was obtained from the relationship between retained energy and metabolizable energy intake (IAME), according Faria Filho et al. (2007).

Protein metabolism was determined by nitrogen intake, retention, excretion and efficiency, according Faria Filho et al. (2007). Nitrogen intake (NI) was calculated through feed intake and diet nitrogen content. Nitrogen retention (NR) was determined by the difference between the birds at 42 and 21 days. Nitrogen efficiency (NEF) was calculated by the relationship between the nitrogen retention and intake. Nitrogen excretion (NE) was estimated by the difference between the nitrogen intake and retention. Nitrogen intake, retention, and excretion were expressed in grams and efficiency was expressed as percentage.

\subsection{Statistical analysis}

The results are presented as means with the pooled standard error of the mean (SEM). All statistical analyses were performed using SAS statistical package (SAS Institute, 2001). All data were analyzed by ANOVA, after the homogeneity of variance between treatments was found by Levene's test (Petrie and Watson, 2006) and the normality by Cramér-von Mises test (Sprent, 1989). Mortality percentage data were normalized by arcsine transformation prior to ANOVA analysis. Treatment means were compared by Tukey's HSD test when differences were significant at $\mathrm{P}<0.05$.

\section{Results}

\subsection{Growth performance}

Table 3 shows the performance results. As expected, the control treatment $(22 \mathrm{C} / \mathrm{AL})$ had higher FI and BWG than the other treatments $(\mathrm{P}<0.01)$. There was a difference for these two variables between continuous (32C/AL) and cyclic stress (CY/AL), and were higher for the $C Y / A L$ birds $(\mathrm{P}<0.01)$. As regards $\mathrm{BWG}$, comparing treatments 32C/AL vs 22C/AL and 22C/PF32C vs 22C/AL, the reduction was 0.764 and $0.530 \mathrm{~kg}$, respectively. Thus, the difference in weight gain in continuously stressed birds is partly due to the decrease in feed consumption and partly due to the specific effect of environmental temperature.

It is estimated that $70 \%(0.530 / 0.764 \mathrm{~kg})$ of the loss in weight gain was due to lower feed intake while 30\% was due to other factors, such as physiological changes induced by temperature per se. When performing the same comparison in the cyclic stressed birds (CY/AL vs. 22C/AL and 22C/PFCY), the effect on weight gain losses was observed to be exclusively due to lower feed intake, since there was no difference between CY/AL and 22C/ PFCY treatments (BWG $=1.619$ and $1.689 \mathrm{~kg}$, respectively).

For the variable $\mathrm{FCR}$, the specific effect of temperature was found only for the 32C/AL treatment $(P<0.01)$, since in the pairfed broilers $(22 \mathrm{C} / \mathrm{PF} 32 \mathrm{C})$ FCR was not different $(\mathrm{P}>0.05)$ from the
Table 3

Feed intake (FI), body weight gain (BWG), feed conversion rate (FCR), and mortality (MORT) of broilers from 21 to 42 days of age raised in different environmental conditions and feed regimens.

\begin{tabular}{lllll}
\hline Treatments $^{1}$ & FI (kg) & BWG (kg) & FCR (kg/kg) & MORT (\%) \\
\hline 22C/AL & $3.369^{\mathrm{a}}$ & $2.021^{\mathrm{a}}$ & $1.67^{\mathrm{ab}}$ & 2.23 \\
$\mathbf{3 2 C} / \mathbf{A L}$ & $2.498^{\mathrm{c}}$ & $1.257^{\mathrm{d}}$ & $1.99^{\mathrm{c}}$ & 2.23 \\
$\mathbf{2 2 C} / \mathbf{P F 3 2 C}$ & $2.483^{\mathrm{c}}$ & $1.491^{\mathrm{c}}$ & $1.72^{\mathrm{ab}}$ & 2.23 \\
$\mathbf{C Y} / \mathbf{A L}$ & $2.820^{\mathrm{b}}$ & $1.619^{\mathrm{b}}$ & $1.74^{\mathrm{bc}}$ & 3.35 \\
$\mathbf{2 2 C} / \mathbf{P F C Y}$ & $2.805^{\mathrm{b}}$ & $1.689^{\mathrm{b}}$ & $1.66^{\mathrm{a}}$ & 1.12 \\
SEM & 0.033 & 0.020 & 0.017 & 1.37 \\
P value & $<0.0001$ & $<0.0001$ & $<0.0001$ & 0.8559 \\
\hline
\end{tabular}

${ }^{1} 22 \mathrm{C} / \mathrm{AL}$ : Birds raised in continuous $22^{\circ} \mathrm{C}$ and ad libitum feeding. $32 \mathrm{C} / \mathrm{AL}$ : Birds raised in continuous high temperature $\left(32^{\circ} \mathrm{C}\right)$ and ad libitum feeding. $22 \mathrm{C} / \mathrm{PF} 32 \mathrm{C}$ : Birds raised in continuous $22^{\circ} \mathrm{C}$ and pair-fed to the $32 \mathrm{C} / \mathrm{AL}$ treatment. $\mathrm{CY} / \mathrm{AL}$ : Birds raised in cyclic high temperature $\left(8 \mathrm{~h}\right.$ at $32^{\circ} \mathrm{C}$ and $12 \mathrm{~h}$ at $\left.25^{\circ} \mathrm{C}\right)$ and ad libitum feeding. $22 \mathrm{C} / \mathrm{PFCY}$ : Birds raised in $22^{\circ} \mathrm{C}$ and pair-fed to the $\mathrm{CY} / \mathrm{AL}$ treatment; $\mathrm{n}=90$ for each treatment group.

${ }^{2}$ SEM - pooled standard error of the mean.

${ }^{\mathrm{a}-\mathrm{d}}$ Means in the same column with different letters differ $(\mathrm{P}<0.05)$.

Table 4

Digestibility coefficients of dry matter (DMD), crude protein (CPD), and crude fat (CFD) and apparent metabolizable energy corrected for nitrogen balance content $\left(\mathrm{AME}_{\mathrm{n}}\right)$ of broilers from 39 to 42 days of age raised in different environmental conditions and feed regimens.

\begin{tabular}{lllll}
\hline Treatments $^{1}$ & DMD (\%) & CPD (\%) & CFD (\%) & AME $_{\mathbf{n}}$ (MJ/kg) \\
\hline 22C/AL & $74.89^{\mathrm{a}}$ & $61.36^{\mathrm{a}}$ & $86.16^{\mathrm{ab}}$ & 11.92 \\
$\mathbf{3 2 C / A L}$ & $71.96^{\mathrm{b}}$ & $55.38^{\mathrm{b}}$ & $83.80^{\mathrm{b}}$ & 11.90 \\
$\mathbf{2 2 C} / \mathbf{P F 3 2 C}$ & $74.29^{\mathrm{a}}$ & $59.10^{\mathrm{ab}}$ & $87.48^{\mathrm{a}}$ & 11.90 \\
CY/AL & $73.25^{\mathrm{ab}}$ & $58.89^{\mathrm{ab}}$ & $83.49^{\mathrm{b}}$ & 11.93 \\
$\mathbf{2 2 C} /$ PFCY & $74.25^{\mathrm{a}}$ & $59.83^{\mathrm{a}}$ & $87.08^{\mathrm{ab}}$ & 11.89 \\
SEM $^{2}$ & 0.49 & 0.88 & 0.82 & 0.03 \\
P value & 0.0034 & 0.0020 & 0.0073 & 0.8255 \\
\hline
\end{tabular}

${ }^{1} 22 \mathrm{C} / \mathrm{AL}$ : Birds raised in continuous $22^{\circ} \mathrm{C}$ and ad libitum feeding. $32 \mathrm{C} / \mathrm{AL}$ : Birds raised in continuous high temperature $\left(32^{\circ} \mathrm{C}\right)$ and ad libitum feeding. $22 \mathrm{C} / \mathrm{PF} 32 \mathrm{C}$ : Birds raised in continuous $22^{\circ} \mathrm{C}$ and pair-fed to the $32 \mathrm{C} / \mathrm{AL}$ treatment. $\mathrm{CY} / \mathrm{AL}$ : Birds raised in cyclic high temperature $\left(8 \mathrm{~h}\right.$ at $32^{\circ} \mathrm{C}$ and $12 \mathrm{~h}$ at $\left.25^{\circ} \mathrm{C}\right)$ and ad libitum feeding. 22C/PFCY: Birds raised in $22^{\circ} \mathrm{C}$ and pair-fed to the $\mathrm{CY} / \mathrm{AL}$ treatment; $\mathrm{n}=90$ for each treatment group.

${ }^{2}$ SEM - pooled standard error of the mean.

${ }^{\text {ab }}$ Means in the same column with different letters differ $(\mathrm{P}<0.05)$.

control birds (22C/AL). The treatments had no significant effect on mortality (MORT) $(\mathrm{P}=0.8559)$.

\subsection{Nutrient digestibility}

Cyclic stress did not affect the dry matter (DMD), crude protein (CPD), and crude fat (CFD) digestibility coefficients $(P>0.05)$ (Table 4). On the other hand, the specific effect of temperature was found for the continuously stressed birds (32C/AL vs. 22C/AL); reducing DMD $(\mathrm{P}<0.01)$ and $\mathrm{CPD}(\mathrm{P}<0.01)$. Apparent metabolizable energy corrected for nitrogen balance content $\left(\mathrm{AME}_{\mathrm{n}}\right)$ was not affected by any experimental treatment $(\mathrm{P}=0.82)$.

\subsection{Energy and protein metabolism}

The specific effects of high temperature and feed consumption affect the results differently for the energy metabolism variables in birds subjected to continuous stress (Table 5). The IAME was higher in the $32 \mathrm{C} / \mathrm{AL}\left(1.84 \mathrm{MJ} / \mathrm{kg}^{0.75} /\right.$ day $)$ treatment in relation to

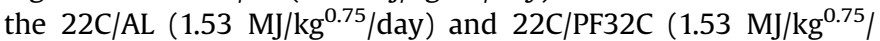
day) treatments $(P<0.01)$, showing the specific influence of heat stress. Similarly, heat production (HP) was higher in the $32 \mathrm{C} / \mathrm{AL}$ $\left(1.49 \mathrm{MJ} / \mathrm{kg}^{0.75} /\right.$ day $)$ in comparison to $22 \mathrm{C} / \mathrm{AL}\left(1.10 \mathrm{MJ} / \mathrm{kg}^{0.75} /\right.$ day $)$ and $22 \mathrm{C} / \mathrm{PF} 32 \mathrm{C}\left(1.20 \mathrm{MJ} / \mathrm{kg}^{0.75} /\right.$ day $)$ treatments $(\mathrm{P}<0.01)$. 
Table 5

Apparent metabolizable energy ingestion (IAME), energy retention (ER), heat production (HP,) and energy efficiency (EE) of broilers from 21 to 42 days of age raised in different environmental conditions and feed regimens.

\begin{tabular}{|c|c|c|c|c|}
\hline Treatments $^{1}$ & $\begin{array}{l}\text { IAME }\left(\mathrm{MJ} / \mathrm{kg}^{0.75} /\right. \\
\text { day) }\end{array}$ & $\begin{array}{l}\text { ER }\left(M \mathrm{M} / \mathrm{kg}^{0.75} /\right. \\
\text { day) }\end{array}$ & $\begin{array}{l}\text { HP }\left(M J / \mathrm{kg}^{0.75} /\right. \\
\text { day) }\end{array}$ & EE (\%) \\
\hline 22C/AL & $1.53^{\mathrm{b}}$ & $0.43^{\mathrm{a}}$ & $1.10^{\mathrm{b}}$ & $27.8^{\mathrm{a}}$ \\
\hline 32C/AL & $1.84^{\mathrm{a}}$ & $0.34^{\mathrm{b}}$ & $1.49^{\mathrm{a}}$ & $18.8^{\mathrm{c}}$ \\
\hline 22C/PF32C & $1.53^{\mathrm{b}}$ & $0.33^{\mathrm{b}}$ & $1.20^{\mathrm{b}}$ & $21.6^{\mathrm{bc}}$ \\
\hline CY/AL & $1.54^{\mathrm{b}}$ & $0.41^{\mathrm{a}}$ & $1.13^{\mathrm{b}}$ & $26.4^{\mathrm{a}}$ \\
\hline 22C/PFCY & $1.45^{\mathrm{b}}$ & $0.37^{\mathrm{ab}}$ & $1.08^{\mathrm{b}}$ & $25.4^{\mathrm{ab}}$ \\
\hline SEM $^{2}$ & 0.02 & 0.02 & 0.03 & 1.10 \\
\hline$P$ value & $<0.0001$ & 0.0005 & $<0.0001$ & $<0.0001$ \\
\hline
\end{tabular}

${ }^{1} 22 \mathrm{C} / \mathrm{AL}$ : Birds raised in continuous $22^{\circ} \mathrm{C}$ and ad libitum feeding. $32 \mathrm{C} / \mathrm{AL}$ : Birds raised in continuous high temperature $\left(32^{\circ} \mathrm{C}\right)$ and ad libitum feeding. $22 \mathrm{C} / \mathrm{PF} 32 \mathrm{C}$ : Birds raised in continuous $22^{\circ} \mathrm{C}$ and pair-fed to the $32 \mathrm{C} / \mathrm{AL}$ treatment. $\mathrm{CY} / \mathrm{AL}$ : Birds raised in cyclic high temperature $\left(8 \mathrm{~h}\right.$ at $32^{\circ} \mathrm{C}$ and $12 \mathrm{~h}$ at $\left.25^{\circ} \mathrm{C}\right)$ and ad libitum feeding. $22 \mathrm{C} / \mathrm{PFCY}$ : Birds raised in $22^{\circ} \mathrm{C}$ and pair-fed to the $\mathrm{CY} / \mathrm{AL}$ treatment; $\mathrm{n}=12$ for each treatment group.

${ }^{2}$ SEM - pooled standard error of the mean.

${ }^{\mathrm{ab}}$ Means in the same column with different letters differ $(\mathrm{P}<0.05)$.

Table 6

Nitrogen ingestion (NI), nitrogen retention (NR), nitrogen excretion (NE), and nitrogen efficiency (NEF) of broilers from 21 to 42 days of age raised in different environmental conditions and feed regimens.

\begin{tabular}{lllll}
\hline Treatments $^{1}$ & NI (kg/bird) & NR (kg/bird) & NE (kg/bird) & NEF (\%) \\
\hline 22C/AL & $0.938^{\mathrm{a}}$ & $0.568^{\mathrm{a}}$ & $0.369^{\mathrm{ab}}$ & $60.7^{\mathrm{ab}}$ \\
32C/AL & $0.696^{\mathrm{c}}$ & $0.282^{\mathrm{d}}$ & $0.413^{\mathrm{a}}$ & $40.6^{\mathrm{c}}$ \\
22C/PF32C & $0.691^{\mathrm{c}}$ & $0.386^{\mathrm{c}}$ & $0.305^{\mathrm{bc}}$ & $55.9^{\mathrm{b}}$ \\
CY/AL & $0.785^{\mathrm{b}}$ & $0.452^{\mathrm{b}}$ & $0.333^{\mathrm{bc}}$ & $57.6^{\mathrm{ab}}$ \\
22C/PFCY & $0.781^{\mathrm{b}}$ & $0.504^{\mathrm{b}}$ & $0.277^{\mathrm{c}}$ & $64.6^{\mathrm{a}}$ \\
SEM $^{2}$ & 0.01 & 0.01 & 0.02 & 1.96 \\
P value & $<0.0001$ & $<0.0001$ & $<0.0001$ & $<0.0001$ \\
\hline
\end{tabular}

${ }^{1} 22 \mathrm{C} / \mathrm{AL}$ : Birds raised in continuous $22^{\circ} \mathrm{C}$ and ad libitum feeding. $32 \mathrm{C} / \mathrm{AL}$ : Birds raised in continuous high temperature $\left(32^{\circ} \mathrm{C}\right)$ and ad libitum feeding. $22 \mathrm{C} / \mathrm{PF} 32 \mathrm{C}$ : Birds raised in continuous $22^{\circ} \mathrm{C}$ and pair-fed to the $32 \mathrm{C} / \mathrm{AL}$ treatment. $\mathrm{CY} / \mathrm{AL}$ : Birds raised in cyclic high temperature $\left(8 \mathrm{~h}\right.$ at $32^{\circ} \mathrm{C}$ and $12 \mathrm{~h}$ at $\left.25^{\circ} \mathrm{C}\right)$ and ad libitum feeding. $22 \mathrm{C} / \mathrm{PFCY}$ : Birds raised in $22^{\circ} \mathrm{C}$ and pair-fed to the $\mathrm{CY} / \mathrm{AL}$ treatment; $\mathrm{n}=12$ for each treatment group.

${ }^{2}$ SEM - pooled standard error of the mean.

${ }^{\text {ab }}$ Means in the same column with different letters differ $(\mathrm{P}<0.05)$

For the ER and EE variables, there was a specific effect of feed intake, since the $32 \mathrm{C} / \mathrm{AL}\left(0.34 \mathrm{MJ} / \mathrm{kg}^{0.75} / \mathrm{day}\right.$ for ER and $18.8 \%$ for $\mathrm{EE})$ and the $22 \mathrm{C} / \mathrm{PF} 32 \mathrm{C}\left(0.33 \mathrm{MJ} / \mathrm{kg}^{0.75} /\right.$ day for ER and $21.6 \%$ for $\left.\mathrm{EE}\right)$ treatments differed from the 22C/AL $\left(0.43 \mathrm{MJ} / \mathrm{kg}^{0.75} /\right.$ day and $27.8 \%$ for ER and EE respectively; $\mathrm{P}<0.01)$, but did not differ from each other $(P>0.01)$.

For protein metabolism (Table 6), lower nitrogen ingestion (NI) $(\mathrm{P}<0.01)$ was observed in birds under continuous stress $(22 \mathrm{C} / \mathrm{AL}$ vs. 32C/AL; 0.938 vs $0.696 \mathrm{~kg} \mathrm{NI} /$ bird). This was due to lower feed intake, since the $32 \mathrm{C} / \mathrm{AL}$ and $22 \mathrm{C} / \mathrm{PF} 32 \mathrm{C}$ values were not different (0.696 vs $0.691 \mathrm{~kg} \mathrm{NI} /$ bird, respectively; $\mathrm{P}>0.05)$. The nitrogen retention (NR) was $51 \%(0.287 \mathrm{~kg} \mathrm{NR} /$ bird $)$ and $32 \%(0.183 \mathrm{~kg} \mathrm{NR} /$ bird) lower in 32C/AL and 22C/PF32C birds, respectively, in comparison to the $22 \mathrm{C} / \mathrm{AL}$ treatment $(\mathrm{P}<0.01)$. Thus, it was estimated that $64 \%(0.183 / 0.287)$ of lower nitrogen ingestion was due to the drop in feed consumption and $36 \%$ due to the specific effect of temperature.

As there were no differences for nitrogen excretion (NE) in relation to constant stress $(\mathrm{P}>0.05)$, nitrogen efficiency (NEF) was lower in the $32 \mathrm{C} / \mathrm{AL}(40.6 \%)$ treatment than in treatments $22 \mathrm{C} / \mathrm{AL}$ $(60.7 \%)$ and $22 \mathrm{C} / \mathrm{PF} 32 \mathrm{C}(55.9 \%)(\mathrm{P}<0.01)$, showing the specific effect of temperature. For birds under cyclic stress, the effect of lower feed intake (22C/AL vs. 22C/PFCY and CY/AL) was also found, reducing the NI of stressed birds $(\mathrm{P}<0.01)$. On the other hand, the $\mathrm{NE}$ of birds of the 22C/PFCY treatment decreased in comparison to the $22 \mathrm{C} / \mathrm{AL}$ treatment $(0.277$ vs $0.369 \mathrm{~kg} /$ bird, $\mathrm{P}<0.01)$.

\section{Discussion}

A large number of studies on chicken heat stress have been published, with the majority of them using continuous heat as the investigative model. However, birds are not exposed to this condition in normal farming environments. More appropriate models representing the cyclic temperatures which naturally occur during hot summer months (Dale and Fuller, 1980; Mashaly et al., 2004), require further investigation.

Dale and Fuller (1980), using the same experimental procedure (continuous and cyclical), found that broiler chickens reared under a cool environment and pair-fed at the same level of feed intake as those in hot environment gained more body weight. The authors concluded that factors other than reduced feed intake, but still dependent on high temperature, could be involved in growth reduction. Furthermore, their morphophysiological studies revealed that the thyroid gland was smaller in birds submitted to continuous heat than at cyclical temperature.

The findings of this study revealed that broiler chicken growth was reduced by both continuous and cyclic heat stress as previously reported by other authors (Dale and Fuller, 1980; Ferket and Gernat, 2006; Sohail et al., 2012). Moreover, the pair-feeding experimental schedule showed that $70 \%$ of the reduced body weight gain in continuously stressed birds was due to the reduction in feed intake and 30\% due to temperature exposure per se. These numbers confirm the hypothesis raised by the meta-analysis carried out by Mignon-Grasteau et al. (2015) - that the reduction in feed intake is the main cause of the effect on the other performance traits in heat stressed laying hens - is also true for broilers. On the other hand, cyclical heat stress only affected growth due to the reduction in feed intake.

It is known that continuous heat stress strongly affects nutrient utilization (Cooper and Washburn, 1998; Longo et al., 2006; Ferket and Gernat, 2006; Piestun et al., 2011; Song et al., 2012). However, to our knowledge, there are no works comparing continuous and cyclic heat stress on performance and metabolic parameters of broiler chickens.

Known effects of heat stress in the digestive function include such things as modifications on hypothalamic peptides involved in appetite regulation (Song et al., 2012); a decreased passage rate of feed residue, decreased trypsin, chymotrypsin, and amylase activity (Hai et al., 2000); and changes in intestinal morphology and nutrient absorption (Mitchell and Carlisle, 1992). These effects can explain the poor feed efficiency and also contribute to the lower dry matter and protein digestibility we observed in the continuously heat stressed birds. Previous works showed the same results for dry matter, protein (Bonnet et al., 1997; Puvadolpirod and Thaxton, 2000), and amino acids (Geraert et al., 1992; Larbier et al., 1993).

The lower energy efficiency found in the continuously exposed birds (compared to those exposed cyclically), reflects the large energy demand for maintenance, especially for body temperature regulation (Piestun et al., 2011). Thermoregulation maintenance in birds is achieved by diverse mechanisms, including enhanced radiant, convective, and evaporative heat loss, in addition to greater air circulation in the air sacs (Lara and Rostagno, 2013). All of these mechanisms come at a great energetic expense to the animal, and lead to lower energy efficiency.

Geraert et al. (1996) and Longo et al. (2006) have linked the lower energy retention and efficiency to reduced feed consumption in continuously heat exposed birds, but this was not observed 
in our work that employed pair-feeding schedule. In this study, the higher heat production observed under continuous heat stress was the determinant for their lower energy efficiency. For cyclically exposed birds, in spite of feed intake reduction, were not observed modifications in energy retention and energy efficiency. Thus, our results suggested that cyclic stress allows the birds to have better control of their body temperature, conserving energy demand, and not influencing the energy efficiency.

These results strongly revealed differences between the effects of continuous or cyclical heat exposure in birds. Although both models cause impaired performance, under cyclic stress conditions the physiological reactions to the heat are attenuated during milder temperature periods, thereby resulting in less damage than under continuous heat exposure. Thus, the industry application of results from studies on continuous heat exposure should be reviewed, as this environmental condition does not exist on the farm.

\section{Conclusion}

In conclusion, the results support the hypothesis that growth performance, nutrient digestibility, and energy and nitrogen balances in broiler chickens respond differently to either continuous or cyclic heat stress. Both continuous and cyclical heat stress affects broiler performance, but in different magnitudes, decreasing BWG by $36 \%$ and $21 \%$, respectively. However, the efficiency of nutrient utilization and energy metabolism were only affected by the continuous heat exposure, decreasing $9.7 \%$ protein digestibility and $32.4 \%$ energy efficiency of broilers.

\section{Conflict of interest statement}

There is absolutely no conflict of interest with any individual or organization regarding the materials discussed in the manuscript.

\section{References}

Abu-Dieyeh, Z.H.M., 2006. Effect of high temperature per se on growth performance of broilers. Int. J. Poult. Sci. 5, 19-21.

AOAC, 1984. Official Methods of Analysis, 14th ed. Association of Official Analytical Chemist, Washington, DC.

Blaxter, K., 1989. Energy Metabolism in Animals and Man. Cambridge University Press, Cambridge, UK.

Bonnet, S., Geraert, P.A., Lessire, M., Carre, B., Guillaumin, S., 1997. Effect of high ambient temperature on feed digestibility in broilers. Poult. Sci. 76, 857-863.

Clark, W.D., Classen, H.L., 1995. The effects of continuous or diurnally fed melatonin on broiler performance and health. Poult. Sci. 74, 1900-1904.

Cooper, M.A., Washburn, K.W., 1998. Relationships of body temperature to weight gain, feed consumption, and feed utilization in broiler under heat stress. Poult. Sci. 77, 237-242.

Dale, N.M., Fuller, H.L., 1979. Effects of diet composition on feed intake and growth of chicks under heat stress. I. Dietary fat levels. Poult. Sci. 58, 1529-1534.

Dale, N.M., Fuller, H.L., 1980. Effect of diet composition on feed intake and growth of chicks under heat stress: II. Constant vs cycling temperatures. Poult. Sci. 59, 1434-1441.

Faria Filho, D.E., Campos, D.M.B., Torres, K.A.A., Vieira, B.S., Rosa, P.S., Vaz, A.M., Macari, M., Furlan, R.L., 2007. Protein levels for heat exposed broilers: performance, nutrients, digestibility and energy and protein metabolism. Int. J. Poult. Sci. 6, 187-194.
Ferket, P.R., Gernat, A.G., 2006. Factors that affect feed intake of meal bird: a review. Int. J. Poult. Sci. 5, 905-911.

Geraert, P.A., Guillaumin, S., Zuprizal, L.M., 1992. Effect of high ambient temperature on dietary metabolizable energy value in genetically lean and fat chickens. Poult. Sci. 71, 2113-2116.

Geraert, P.A., Padilha, J.C.F., Guillaumin, S., 1996. Metabolic and endocrine changes induced by chronic heat exposure in broiler chickens: growth performance, body composition and energy retention. Br. J. Nutr. 75, 195-204.

Gonzales-Esquerra, R., Leeson, S., 2006. Physiological and metabolic responses of broilers to heat stress - implications for protein and amino acid nutrition. World Poult. Sci. J. 62, 282-295.

Gregory, N.G., 2010. How climatic changes could affect meat quality. Food Res. Int. 43, 1866-1873.

Hai, L., Rong, D., Zhang, Z.Y., 2000. The effect of environment on the digestion of broilers. J. Anim. Physiol. Anim. Nutr. 83, 57-64.

Hill, F.W., Anderson, D.L., 1958. Comparison of metabolizable energy and productive energy determinations with growing chicks. J. Nutr. 64, 587-604.

Keshavarz, K., Fuller, H.L., 1980. The influence of widely fluctuating temperatures on heat production and energetic efficiency of broilers. Poult. Sci. 59 2121-2128.

Lara, L.J., Rostagno, M.H., 2013. Impact of heat stress on poultry production. Animals 3, 356-369.

Larbier, Z.M., Chagneau, A.M., Geraert, P.A., 1993. Influence of ambient temperature on true digestibility of protein and amino acids of rapeseed and soybean meals in broilers. Poult. Sci. 72, 289-295.

Longo, F.A., Sakomura, N.K., Rabello, C.B.V., Figueiredo, A.N., Fernandes, J.B.K., 2006. Exigências energéticas para mantença e para o crescimento de frangos de corte. R. Bras. Zootec. 36, 119-126.

Mashaly, M.M., Hendricks, G.L., Kalama, M.A., Gehad, A.E., Abbas, A.O., Patterson, P. H., 2004. Effect of heat stress on production parameters and immune responses of commercial laying hens. Poult. Sci. 83, 889-894.

Mignon-Grasteau, S., Moreri, U., Narcy, A., Rousseau, X., Rodenburg, T.B., TixierBoichard, M., Zerjal, T., 2015. Robustness to chronic heat stress in laying hens: a meta-analysis. Poult. Sci. 94, 586-600.

Mitchell, M.A., Carlisle, A.J., 1992. The effect of chronic exposure to elevated temperature on intestinal morphology and nutrient absorption in the domestic fowl (Gallus domesticus). Comp. Biochem. Physiol. A 101, 137-142.

Nardone, A., Ronchi, B., Lacetera, N., Raniere, M.S., Bernabucci, U., 2010. Effects of climate changes on animal production and sustainability of livestock systems. Livest. Sci. 130, 57-69.

Petrie, A., Watson, P., 2006. Statistics for Veterinary and Animal Science, second ed. Blackwell Publishing, Oxford, UK, pp. 158-190.

Phetteplace, H.W., Nockels, C.E., 1985. Melatonin increases cockerel growth. Fed. Proc. 44, 761 (Abstr.).

Piestun, Y., Halevy, O., Shinder, D., Ruzal, M., Druyan, S., Yahav, S., 2011. Thermal manipulations during broiler embryogenesis improves post-hatch performance under hot conditions. J. Therm. Biol. 36, 469-474.

Puvadolpirod, S., Thaxton, J.P., 2000. Model of physiological stress in chickens 4. Digestion and metabolism. Poult. Sci. 79, 383-390.

Rostagno, H.S., Albino, L.F.T., Donzele, J.L., Gomes, P.C., Oliveira, R.F., Lopes, D.C. Soares, A.F., Barreto, L.S.T., 2005. Brazilian Tables for Poultry and Swine: Composition of Feedstuffs and Nutritional Requirements, 2nd ed. Universidade Federal de Viçosa, Vicosa, MG, Brazil.

SAS Institute, 2001. SAS/STAT ${ }^{\circledR}$ User's Guide (Reléase 8.2). SAS Institute Inc., Cary NC, USA.

Sohail, M.U., Hume, M.E., Byrd, J.A., Nisbet, D.J., Ijaz, A., Sohail, A., Shabbir, M.Z., Rehman, H., 2012. Effect of supplementation of prebiotic mannan-oligosaccharides and probiotic mixture on growth performance of broilers subjected to chronic heat stress. Poult. Sci. 91, 2235-2240.

Song, Z., Liu, L., Sheikhahmadi, A., Jiao, H., Lin, H., 2012. Effect of heat exposure on gene expression of feed intake regulatory peptides in laying hens. J. Biomed. Biotechnol. 2012, 1-8.

Sprent, P., 1989. Applied Nonparametric Statistical Methods. Chapman and Hall, London.

Temim, S., Chagneau, A.M., Guillaumin, S., Michel, J., Peresson, R., Geraert, P.A., Tesseraud, S., 1999. Effects of chronic heat exposure and protein intake on growth, performance, nitrogen retention and muscle development in broiler chickens. Reprod. Nutr. Dev. 39, 145-156.

Temim, S., Chagneau, A.M., Peresson, R., Tesseraud, S., 2000. Chronic heat exposure alters protein turnover of three different skeletal muscles in finishing broiler chickens fed 20 or 25\% protein diets. J. Nutr. 130, 813-819.

Yamazaki, M., Zi-Yi, Z., 1982. A note on the effect of temperature on true and apparent metabolisable energy values of a layer diet. Br. Poult. Sci. 23, 447-450. 